\title{
Perspective of Samara-Canadian Relations in the Tourism
}

\author{
Gleb Aleksushin \\ Samara State Economic University, Samara, Russia, Correspondence: Gleb Aleksushin \\ Samara State Economic University Samara, Sovetskoj Armii, 141, Russia. Email: gva3@yandex.ru
}

\section{Doi:10.5901/mjss.2015.v6n6s3p323}

\begin{abstract}
The modern tourist industry is one of the most dynamically developing sectors of world economy and contributes significantly to the formation of the gross domestic product, increase of the balance of payments. It plays an important role in the socioeconomic development of the state, contributes to improving the quality of life of the population. In addition, the tourism industry relates to sectors that have significant multiplicative effect in terms of the creation of demand for products related sectors of the economy and employment of the population. At the moment Samara region-Canadian relations in tourism are lacking. There are no studies on this topic. The problem, however, is: the flow of tourists increases every year. Samara tourists increasingly travel abroad, including to Canada. Canadian tourists often visit Russia, but to Samara are rarely. What steps need to be taken to change the situation?
\end{abstract}

Keywords: Europe, Canada, Samara, Samara region, tourism, tourist, tourist product

\section{Introduction}

The number of tourists in the world is constantly increasing.

Thus, the proportion of tourists visiting classic Europe, is gradually declining. European tourist product aging, $90 \%$ of its users - the Europeans (Bondarovich, Recreational, 2003).

America ranks 3rd in the world in the number of foreign tourists, and Canada with the US is half of the tourist flow to the continent.

The number of tourists to Russia is growing, albeit slowly (Table 1). Increases the flow of Canadian tourists to our country. However, Samara gets very small part of this flow. Samara region, despite the rich tourism resources, inadequate levels of tourism. One of the main problems in the formation of this situation was the secrecy in which Samara region lived until 1991.

For Canada, the changing balance of incoming and outgoing tourists is also a problem: the amount of traveling has increased between 2000 and 2010, from 19 to 28 million tourists, and traveling has decreased in the same period of time from 19 to 16 million.

These problems pose to Canada and the Samara region the same problem of the need to increase foreign tourism. And, the best way to solve these problems together - Increasing streams of tourists to each other. With the help of this approach, Canada and the Samara region will be able to increase the number of tourists on its territory. What you need to do?

For beginning, the necessary analysis of the problems in the organization of tourism from Samara region (Russia) and Canada.

\section{Method}

Methods major - comparative analysis, search of interesting resources, the search directions of development of tourism.

The comparison of climate data and data on tourism flows from Canada to Russia and from Russia to Canada will give an idea about the state of Russian-canadian tourism and the possible directions of its development.

In Samara it is necessary to find interesting for Canadians natural, historical and cultural resources. In Canada it is necessary to find interesting for Samara's residents natural, historical and cultural resources.

In difficult financial crisis need the use of community efforts in the development of tourism. 


\section{Results}

\subsection{Comparative analysis Canada and Samara region}

The travel of Russian tourists to Canada is a stable on 35 places. Russia in the priorities of canadian tourists varies $11-16$ places (Table 2), accounting for 2\%. The ratio of Russian tourists is to Canadian 1:7 (2008), 1:11 (2009), 1:6 (2010 n 2011). A sharp deterioration in 2009 is a consequence of the crisis.

From Canada to Russia goes more English-speaking tourists than French-speaking ones. Therefore, in Samara, you need to focus on the proposal of the canadian tourists resources of interest to native English speakers.

In many respects, the comparison, the climate of Canada and Samara region are very similar.

\subsection{Interesting resources}

Convenient geographical location of the central part of Russia created the possibility for the development of a large (one of the most significant in Russia) transport interchange hub. Region area of 53,6 thousand $\mathrm{km}^{2}$ and is located in the South-East of the European territory of Russia on the both parts of the course of Volga river in $1098 \mathrm{~km}$ from Moscow. In addition to a wide variety of tourist facilities in Samara there are tourist resources of interest to Canadians. In the XIX century Samara wheat exported to Canada. Perhaps Canadians will be interesting to see in the Grain square with the elevators, where our bread was delivered to their country (Aleksushin, Tours, 2014). In Samara Canadians will be interesting to see the building of the diplomatic mission of Canada to the USSR, 1942-1943 worked on the organization of deliveries of lend-lease in nous the country to fight against Nazi Germany (Aleksushin, Foreign, 2012). According to the ranking for the first quarter of 2013 Samara entered the top Ten Russian Cities that are popular with tourists.

Samara region has all the necessary resources for the active development of almost all kinds of leisure tourism and recreation. Participating, ski and cruise tourism developing successfully, road trips tourist routes becoming more and more popular. In Samara there are many objects associated with Britain, France, and Australia. Only in Samara can be seen standing upright space rocket "Soyuz" with the Museum "Space Samara", 37 metre deep Earth bunker of Stalin, the biggest Kuibyshev square in Europe and 2nd in the world by area, one of the 10 highest monuments (of Glory, 52 meters) in the world, with a length of 8 kilometres of the embankment of the Volga river, formed by a sharp bend of the Volga Samarskaya Luka. Zhiguli mountains preserved ancient originality of the animal and of vegetable world, it was told to the present day features a prehistoric appearance of the Earth. Created by long work of water, sun, wind and surf, about 3 million years ago Zhigulevsky peninsula go into Akchagyl sea. In the region - more than 200 monuments of nature, including the national parks "Samarskaya Luka" and "Buzuluksky Bor", FSBO "Zhigulevsky State Natural Biosphere Reserve of them. I.I. Sprygin" and many unique caves and sources. In the second largest city of Samara region, Toglyatti, you can visit Technical Museum them. K.G. Sakharov JSC «AvtoVAZ» in Togliatti demonstrates to guests military equipment of the 1st and 2nd world wars, modern weapons. The museum has a real submarine length of $90 \mathrm{~m}$ and an armored train, running kart. In a separate pavilion viewers can take pictures in VAZ, did not follow the series. Several places of the Samara region will be of interest to fans of the UFO. Music festivals: International «Rock over the Volga», ethnic music «Drums of the world» and accordion music «Vivat, Bayan», Russian bard song to them Valery Grushin, electronic music and extreme sports «GES-fest», of music festivals «Meta-fest» and others enter the Samara region in the top 5 of Russia in event tourism. Young military-historical nature festivals growing rapidly: the historical martial arts for the Cup CHM «Ancient World», «Military work» (on the site of the Battle of the Kondurcha river 1391) and others. The abundance of transport facilities in the region has led to the emergence and development of technical festivals: "Carfest», «Auto-grad" military-sports show in Bobrovka and others. The multinational composition of the Samara region formed an interest in ethnic festivals, «Syzran tomato», the festival of cherry pie, «Anatologiya» and others. The region has more than 30 health hotels, 125 recreation centers (most of which are located on the river banks), more than 250 hotels. FSBO health hotel «Volzhsky Utes» has frequently been the site of important international meetings, but is available for all guests. FBMO health hotel «Sergievskie Mineralnye Vody», which has existed since 1768, has unique resources. Almost half a century people, which had undergone heart attack and stroke, are going to follow-up care at JSC health hotel them. Chkalov. «Water «Studenaya» from the wells of the Samara branch of FSUO health hotel «Mozhayskiy» on therapeutic effects on the digestive system than many counterparts. Samara region won the right to host the FIFA World Cup in 2018, but this creates a unique opportunity and increased responsibility. In Samara the number of canadian tourists interested in a tour of "Space Samara", as manufactured in Samara space rocket "Soyuz" with which the spacecraft "Soyuz"-TMA-07M with canadian astronaut Christopher Hadfield on board went in 2012 to space. 
Canada is one of the leading countries ranked in 2003 11th place in terms of inbound tourist flow and income from tourism and 12th - expense canadian tourists abroad. The share of Canada in tourist arrivals and ubitech world is 2.5\%, in tourist revenue and expenditure by $2.1 \%$. Incoming and outgoing tourism Canada has a distinct seasonality, due to the climatic conditions of the country. Highest attendances Canada occur in the warmest months of summer, in each of these months of arrival amount to more than 3 million foreigners, while in January only 0.7 million tourists. Seasonality in the travel of Canadians abroad depends on the direction of travel. Although quantitatively for the summer accounts for a third of the annual outbound tourism, winter tourism spending in Canada was 1.5 times higher due to travel distances. For residents of Samara in Canada interested in education and natural objects that are similar in geographic location with Samara. Also will be interesting for them comparable with homeland entertainment - hunting, fishing. The main attractions of Canada is a chain of the Great lakes. In Canada there are thirty four national parks. The largest and most interesting of them are Banff, Wood Buffalo, Glacier. The main directions of foreign tourists coming to Canada - Toronto (3.7 million people), Vancouver and Montreal. Fourth place in popularity among tourists belongs to two small citiescompanions of St. Kenteris and Niagara and connected with the arrival of the falls of Niagara. This resource is actively exploited by tourism, the waterfall built numerous hotels, entertainment enterprises, viewing platform, cable car. To see the falls every year comes up to 2 million people (Canada, 1999)). In Canada is the most beautiful part of the world famous Niagara falls. The whole beauty of it can be seen from the observation deck on the tower in Toronto with a height of 553 meters. It is worth making a trip to the dinosaur Park in the valley of Red deer. Park by UNESCO recognized as a world heritage site. In Canada, more than 2100 of museums with different themes, and historical reserves. In Canada spend a lot of festivals - folklore in Newfoundland, of the hunters in Manitoba, of the Apple trees in Nova Scotia, a costume party of the first settlers and the winter carnival in Quebec, the day of gathering maple sap. Among the tourist objectives of foreign guests there is a very high interest in nature and $21 \%$. Almost $12 \%$ of tourists visit national parks, $2.3 \%$ of tourists come for rafting, kayaking, canoeing or rafting. Popular camping, sports routes, trips on the nature of $6.7 \%$. Thus, the share of the natural component in order for foreign tourism, Canada is among the leading developed countries of the world. Among the goals of arrival is also highlighted in "shopping" (19,7\%), which also allocates Canada among developed countries. This is due to short-term cross-border travel of U.S. residents. High is also the percentage of persons who came to Canada to visit friends and relatives (12.7\%), natural for resettlement countries. Thus, Canada is a country with a highly developed tourism industry, in which the volumes of inbound and outbound tourism are in relative equilibrium. In the last decade in Canada was dominated by the tourism and it is estimated that by 2020 it will retain the lead. According to the WTO among world leaders outbound tourism Canada will occupy the ninth place that will be more than 30 million tourists, or $2 \%$ of world tourist flow. Diversity is the most striking feature of the cultural life of Canada, which is natural for such a big country with a relatively sparse population, which is further divided into numerous groups based on territorial and ethnic lines. First began to show the differences between the two groups that are experts on the history of Canada called natives and first settlers; there were some differences within each of these groups. The natives Indians and Eskimos (Inuit); the first settlers were the French who settled in Nova Scotia and in Quebec in the early 17th century, and the British (English, Scottish and Irish) who settled later in the same century in Nova Scotia, Newfoundland and the shores of Hudson Bay. Canada is so large and diverse attractions, what to do a tourist trip to see the whole country, is hardly possible. For someone who first is going to visit the Northern part of the American continent, the best option is to concentrate your tour to Canada on one or two particularly interesting regions and thoroughly examine them. Each of the canadian regions is unique and can demonstrate to guests the various features of canadian life. At the same time, all parts of the country United by the same high quality of services provided to tourists, a vacation in Canada, will enjoy even the most demanding and experienced traveler.

In the organization of tourism in Canada for residents of Samara region has many problems, among which the basic - additional (compared with other countries) the documents that must be presented to obtain visas. On the official sites of tourism in Canada, there is no Russian language.

For canadian tourists would be interested in this tourist route, whereby they would begin to get acquainted with Russia in the West, perhaps with the Samara region, and from there would go by train on the Trans-Siberian railway, and from the Far East he returned to Canada from the other side. Get a mini-trip around the world, which could be called Around the world through Samara. In Samara could participate in river Zhiguli circumnavigation around Samarskaya Luka, confirmed the idea of the whole tourist route. Given the high level of service the new terminal of the international airport "Kurumoch", and the railway station in Samara, which is considered one of the highest in Europe, and the availability of firms involved in the organization of specialized railway tours, this idea would become the hallmark of the Samara-canadian tourism.

In Samara and Samara region development strategy, including the tourism industry. However, minor attention is given to Canada. In these strategies it is possible to make changes, but this requires political efforts of the canadian side. 
In this case, the administrative resource will provide additional opportunities for development.

In particular, the joint interaction of Canada and Samara region would be the creation of interesting for tourists the Museum exposition in the building in which the canadian mission worked during the second world war. Moreover, this exposure could be interesting not only for canadian tourists, but also residents of Samara and Samara region.

Canadian students would like to participate in our student project forum IVolga, each year passing near Samara in the 3rd week of June.

Requires cooperation at the level of exchange of commands between the military-historical festivals of Canada and Samara region.

Given the active development of sports in recent times in the Samara region, would be beneficial exchanges of sportsmen between Canada and the Samara region for their participation in different sports.

\section{Discussion}

Thus, Samara and Canada interested in each other. For Samara will be a very rewarding experience Canada to the territorial organization of tourism underdeveloped spaces (Totonova, 2010, The model). Russian tourists buy vouchers for a greater number of days among the three spend abroad and always use additional services.

How wishes to turn into a practical result?

\section{Conclusion}

Russia and Canada - the largest state by area in the world. They are located in roughly the same geographical areas and have a similar climate. Our citizens should be interested in tourism to each other, as there is no change of climate and unique natural sites in both countries so much that you can make a wide variety of tourist routes. It is assumed that in incoming tourism by 2020, Canada will descend on 15-16 place, and Russia will rise to 9. Impact advantages of Russia in recreation-geographic location (proximity to European and East Asian tourist markets) and best security historical and cultural recreational resources.

Need public samaro-canadian tourist organization to increase the motivation of tourists both in Canada and in the Samara region, to visit our regions. This organization could take over the organization of education, exchange of delegations, language schools, and economic interaction.

\section{References}

Canada: Guide: With mini-dictionary and maps. (1999). - Moscow: Vanguard.

Statistic of Rosstat (2003). http://www.gks.ru/bgd/reg//b04_42/lssWWW.exe/Stg/d010/i010040r.htm.

TOURest (2009). http://tourest.ru/publ/statistika_turizma_2009.

TOURest (2010). http://tourest.ru/publ/statistika_turizma_2010.

TOURest (2011). http://tourest.ru/publ/statistika_turizma_2011.

Aleksushin, G. V. (2012). Foreign Embassy in Kuibyshev- Moscow (Samara tour route). - Samara: Edelweiss.

Aleksushin, G. V. (2014). Tours in Samara for foreign groups (Samara tour route). - Samara: Prime.

Bondarovich, A. A. (2003). Recreational resources of Europe and their evaluation. - Sunct-Peterburg. SPb: Nevils.

Totonova E. E. (2010). The model of management of regional tourism in the Northern territories of Canada. Problems of modern Economics. (10). http://cyberleninka.ru/article/n/modeli-upravleniya-regionalnym-turizmom-na-primere-severnyh-territoriy-kanady

\section{Appendix}

Table 1. The development of tourism in Russia, Canada and the world, millions people, outlin (place in the world) (Statisic, 2003).

\begin{tabular}{cc}
\hline Years & Tourism in Russia \\
\hline 2004 & $6.6 /$ \\
2005 & $6.78 /$ \\
2006 & $7.75 /$ \\
2008 & $/ 11.3$ \\
2009 & 19.5 \\
2010 & $/ 12.6$ \\
2011 & $114.5(13)$ \\
2012 & $/ 15.3$ \\
2013 & $/ 18.3$ \\
2014 & $/ 12.0$ \\
\hline
\end{tabular}


Table 2. The development of tourism from Russia to Canada and from Canada to Russia, people (places), (TOURest, 2009, 2010, 2011).

\begin{tabular}{ccc}
\hline Years & Russia to Canada & Canada to Russia \\
\hline 2008 & $6724(35)$ & $44238(13)$ \\
2009 & $3819(35)$ & $43642(11)$ \\
2010 & $4898(35)$ & $31536(16)$ \\
2011 & $5494(35)$ & $34926(14)$ \\
\hline
\end{tabular}

